\title{
The morphometric and numerical analysis of five species of Eragrostis sp. Wolf. based on silica bodies in leaf epidermal cells \\ Shilpa Dinda ${ }^{1}$ and Amal Kumar Mondal ${ }^{2 *}$ \\ ${ }^{1}$ Assistant Professor of Botany, Department of Biological Sciences, Midnapore City College, KuturiaBhadutata, Midnapore, Paschim Medinipure-721129, West Bengal, India. \\ 2Plant Taxonomy, Biosystematics and Molecular Taxonomy Laboratory UGS-DRS-SAP and DBT-BOOST-WB \\ Department, Department of Botany \& Forestry Vidyasagar University, Midnapore-721102, West Bengal, India
}

Received: 3/26/2018; Revised: 4/15/2018; Accepted: 4/25/2018

\begin{abstract}
Many plants take up soluablemonosilicic acid from the soil. Some of these plants subsequently deposit it as cell inclusions of characteristic structure commonly known as silica bodies or phytolith. In the family Poaceae, different types of silica bodies are characteristic feature of the different subfamily. Eragrostis sp., belonging to the subfamily Chloridoideae. These micro-morphological characters of silica bodies of five species of Eragrostissp applied numerically by UPGMA method. Out of five species Eragrostis atrovirens and Eragrostis gangetica are very closely related and their pairing affinity value is $90 \%$.
\end{abstract}

Key words: Silica Bodies, Diversity, Numerical Analysis, Dendrogram, Poaceae

\section{Introduction}

All of plants, the grasses are the most important to man. All our breadstuffs, corn, wheat, rye, barley, rice are grasses. In leaves of grasses, silica can constitute 2-5\% dry matter, 10-20 times higher than levels found typically in dicotyledonous plants (Massey et al., 2006). Silica is stored primarily as opaline phytolith in the epidermis (Kaufman et al., 1985). The Si content differs greatly between the plant species because Si uptake differences by the roots. Uptake and translocation occur as monosilicic acid and the deposition from is amorphous silica gel $\mathrm{SiO}_{2} \mathrm{nH}_{2} \mathrm{O}$ (Parry et al., 1984). Phytoliths come in varying shapes and sizes. Although some use "phytolith" to refer to all mineral secretions by plants, it more commonly refers to siliceous plant remains. First, soluble silica, also called monosilicic acid, is taken up from the soil when plant roots absorb groundwater. It is carried to other plant organs through the xylem. By an unknown mechanism, which appears to be linked to genetics and metabolism, some of the silica is then laid down in the plant as silicon dioxide. Few plants have been found with silica in their reproductive and sub-surface. Phytoliths are microscopic silica bodies that precipitate in or between cells of living plant tissues, but are especially abundant, diverse, anddistinctive in the family Poaceae. There are so many taxa in Poaceae are characterized by phytoliths having specific morphological characteristics, which are plays an important taxonomic significance. Phytoliths are released from plant tissues when they are decayed, burned, or digested. Released phytoliths thus become microfossils of the plants that produce them. Phytolith morphology and taxonomy, as well as the application of phytolith analysis to archaeological and paleo-environmental research. Silicon deprived plants grown in conventional nutrient solutions to which silicon has not been added are in many ways experimental artifacts. They are often structurally weaker than silicon enriched plants, abnormal in growth, development, viability and reproduction (Shakoor, 2014). Silica bodiesis essential in plant life cycle.

\section{Materials and Methods}

The five plants (leaf) species of Eragrostis were collected from the study area of Paschim Midnapore (Vidyasagar University Campus) West Bengal, India were collected which may be future authenticated by Global Positioning System GPS (Garmin-10) and it was done in the month from November to February. The leaves are taken and immersed in that FAA solution for at least $24 \mathrm{hrs}$ and next day the preparation of permanent slides and good peeling. After preparing slides were observed under Light Microscope (LM), Polarized Microscope (PM), Fluorescence Microscope (FM) and Scanning Electron Microscope (SEM) for detailed analysis. Camera Lucida drawing and the dendrogram is constructed by the method of UPGMA analysis (Sokal and Sneath,1956).

\section{${ }^{*}$ Corresponding Author:}


Table I. Date and place of collection of selected plant species under the sub-family Chloridoideae.

\begin{tabular}{cllcc}
\hline S.No. & Scientific Name of plants & Sub-family & Place of collection & Date of collection \\
\hline 1. & Eragrostis atrovirens (Desf.) Trin. Ex Steud & Chloridoideae & V.U. Campus & 14.02 .15 \\
2. & Eragrostis ciliaris(L.) R. Br. & Chloridoideae & V.U. Campus & 14.02 .15 \\
3. & Eragrostis coaratataStapf & Chloridoideae & V.U. Campus & 12.12 .14 \\
4. & Eragrostis gangetica $($ Roxb.) Steud. & Chloridoideae & V.U. Campus & 12.12 .14 \\
5. & Eragrostis unioloides(Retz.) Nees ex. Steud & Chloridoideae & V.U. Campus & 12.12 .14 \\
\hline
\end{tabular}

Table II: Length and breadth of Narrow elliptical base shaped silica bodies in the leaf of selected plant taxa under the sub-family Chloridoideae.

\begin{tabular}{clcc}
\hline S. No. & $\begin{array}{c}\text { Scientific name of } \\
\text { the plant species }\end{array}$ & $\begin{array}{c}\text { Mean } \pm \text { Se } \\
\text { (Length) }\end{array}$ & $\begin{array}{c}\text { Mean } \pm \text { Se } \\
\text { (Breadth) }\end{array}$ \\
\hline 1. & Eragrostis atrovirens & $18.64 \pm 1.36$ bcd & $7.05 \pm 0.50$ bcde \\
2. & Eragrostis ciliaris & $15.7 \pm 0.20$ acde & $8.23 \pm 0.75$ acde \\
3. & Eragrostis coaratata & $16.1 \pm 0.16$ abde & $6.52 \pm 0.40$ abde \\
4. & Eragrostis gangetica & $16.86 \pm 0.74$ abce & $8.22 \pm 0.58$ abce \\
5. & Eragrostis unioloides & $11.34 \pm 0.21$ bcd & $6.02 \pm 0.36$ abcd \\
\hline
\end{tabular}

[Values are expressed as Mean \pm SEM. a, b, c, d, e indicates significantly different $(\mathrm{P}<0.05)$ ].

Table II (A). Length of narrow elliptical base shaped silica bodies in the leaf of plant taxa under sub-family Chloridoideae.

\begin{tabular}{ccccccc}
\hline S. No. & Scientific name & Mean \pm Se & Sd $(\mathbf{y E r} \pm)$ & Min & Max & Range \\
\hline 1. & Eragrostisatrovirens & $18.64 \pm 1.36$ bcd & 2.36 & 16.62 & 21.24 & 4.62 \\
2. & Eragrostisciliaris & $15.7 \pm 0.20$ acde & 0.35 & 15.3 & 15.98 & 0.68 \\
3. & Eragrostiscoaratata & $16.1 \pm 0.16$ abde & 0.28 & 15.86 & 16.41 & 0.55 \\
4. & Eragrostisgangetica & $16.86 \pm 0.74$ abce & 1.28 & 16.02 & 18.35 & 2.33 \\
5. & Eragrostisunioloides & $11.34 \pm 0.21$ bcd & 0.42 & 10.77 & 11.78 & 1.01 \\
\hline
\end{tabular}

[Values are expressed as Mean \pm SEM. a, b, c, d, e indicates significantly different $(\mathrm{P}<0.05)$ ].

Table II (B). Breadth of Narrow elliptical base shaped silica bodies in the leaf of selected plant taxa under the sub-family Chloridoideae.

\begin{tabular}{cllcccc}
\hline S. No. & Scientific name & Mean \pm Se & Sd (yEr \pm ) & Min & Max & Range \\
\hline 1. & Eragrostisatrovirens & $7.05 \pm 0.50$ bcde & 0.87 & 6.08 & 7.78 & 1.7 \\
2. & Eragrostisciliaris & $8.23 \pm 0.75$ acde & 1.30 & 6.72 & 9.05 & 2.33 \\
3. & Eragrostiscoaratata & $6.52 \pm 0.40$ abde & 0.69 & 6.03 & 7.32 & 1.29 \\
4. & Eragrostisgangetica & $8.22 \pm 0.58$ abce & 1.00 & 7.34 & 9.32 & 1.98 \\
5. & Eragrostisunioloides & $6.02 \pm 0.36$ abcd & 0.73 & 5.27 & 6.97 & 1.7 \\
\hline
\end{tabular}

[Values are expressed as Mean \pm SEM. a, b, c, d, e indicates significantly different $(\mathrm{P}<0.05)$ ].

Table III. Numerical form of micro-morphological characters for phylogenetic analysis of 5 species of Eragrostis of the subfamily Chloroideae.

\begin{tabular}{|c|c|c|c|c|c|}
\hline & \multirow{2}{*}{ Character } & \multicolumn{4}{|c|}{ Characteristic symbol } \\
\hline & & 0 & 1 & 2 & 3 \\
\hline 1 & Types of Silica bodies & $\begin{array}{c}\text { Narrow elliptical } \\
\text { base }\end{array}$ & & & \\
\hline 2 & Shape of Silica bodies & Concave & Convex & & \\
\hline 3 & Arrangement of Silica bodies & Series & Scattered & & \\
\hline 4 & Position of Silica bodies & Vascular bundle & Mesophyll cells & Both & \\
\hline 5 & Series of Silica bodies & One row & More row & & \\
\hline 6 & Presence of Silica bodies & Monotype & Polytype & & \\
\hline 7 & Long cell margin & Sinuous & Slightly sinuous & Non-sinuous & \\
\hline 8 & Length of Silica bodies & $10-12$ & $13-15$ & 16-18 & \\
\hline 9 & Breadth of Silica bodies & $5-6$ & $7-8$ & $9-10$ & \\
\hline 10 & The ratio of length/breadth of Silica bodies & $1-1.50$ & $1.51-1.99$ & $2-2.50$ & $2.51-2.99$ \\
\hline
\end{tabular}

\section{Results}

Eragrostis atrovirens (Desf.) Trin. Ex Steud (Plate 1)

Perennial, Culms tufted, terete, erect, branched from the base, glabrous, nodes glabrous. Leaf sheath compressed, glabrous, ligule ciliate membranous. Leaf blade flat or convolute, linear, base rounded, glabrous, apex acuminate. Panicles lax, grey, rachis slender, angular, scaberulous, branched filiform, angular. Spikelets narrowly oblong, grey or purplish. Lower glume thinly membranous, narrowly ovate, 1 keeled, 1-nerved, apex acute. Upper glume membranous, narrowly ovate. Lemma membranous, broadly ovate, 3-nerved, apex acute. Palea hyaline, narrowly obovate, 2-keeled, 2-nerved. Lodicules 2. Stamens 3. Caryopsis broadly ovate. 


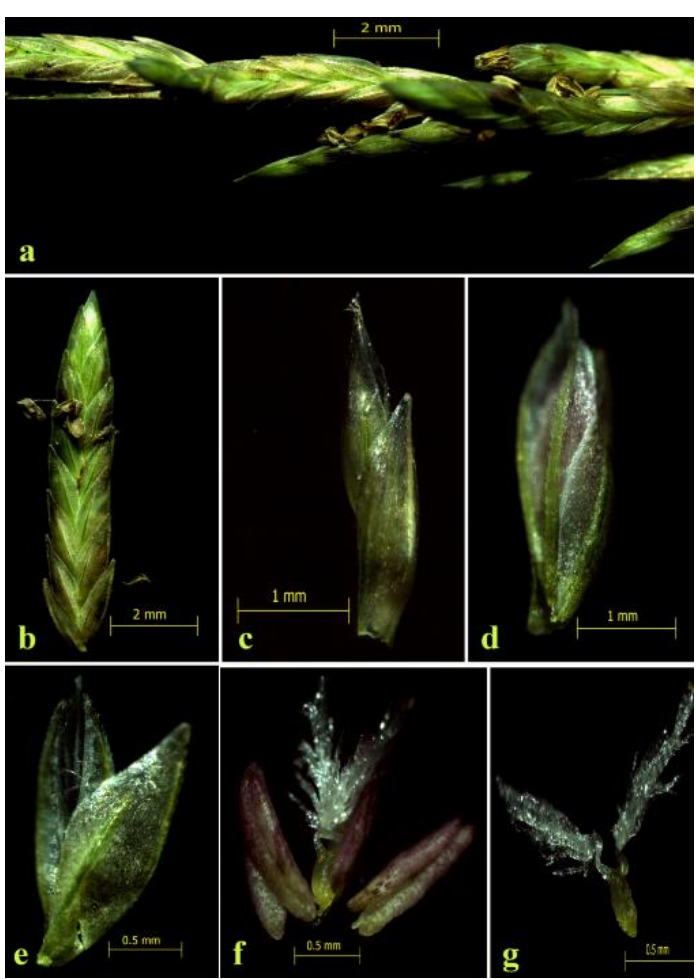

Plate 1. Eragrostis atrovirens a \& b. Rachis; c \& d. Spikelet; e. Lemma and Palea; f. Stamens with pistill; g. Pistil.

\section{Eragrostis ciliaris (L.) R. Br. (Plate 2)}

Annual. Culms tufted, terete, slender, erect, geniculute at base, nodes glabrous. Leaf sheath terete, beareded at mouth, ligule a rim of hairs. Leaf blade flat or convolute, linear, glabrous, apex acuminate. Panicles compact, cylindric, rachis slender, smooth branches short, flexuous. Pedicels very short. Spikeletes compressed, crowded, broadly elliptic ovate, breaking up from above downward. Lower glume membranous, narrowly ovate, 1-keeed, 1-nerved. Upper glume membranous, narrowly ovate, keel scaberulous. Lemma membranous, narrowly oblong, 3-nerved, apex acute. Palea hyaline, oblong, keels with long rigid cilia, apex obtuse. Lodicules 2. Stamens 3. Caryopsis elliptic.

\section{Eragrostis coarctata Stapf (Plate 3)}

Annual, Culms tufted, terete, geniculately ascending, nodes glabrous. Leaf sheath terete, adhering to the culms, bearded just below mouth with long hairs, ligule a rim of white hairs. Leaf blade convolute, linear, glabrous, apex acuminate. Panicles subspiciform, rachis slender, branches very slender. Pedicles very short. Spikelets narrowly oblong, breaking up from above downwards. Lower glume membranous, narrowly ovate, 1-keeled, 1-nerved, apex acute. Upper glume membranous, narrowly ovate, keels scaberulous. Lemma membranous, ovate elliptic, apex obtuse. Palea hyaline, narrowly obovate, keels ciliate. Lodicules 2. Stamen 3. Caryopsis elliptic.

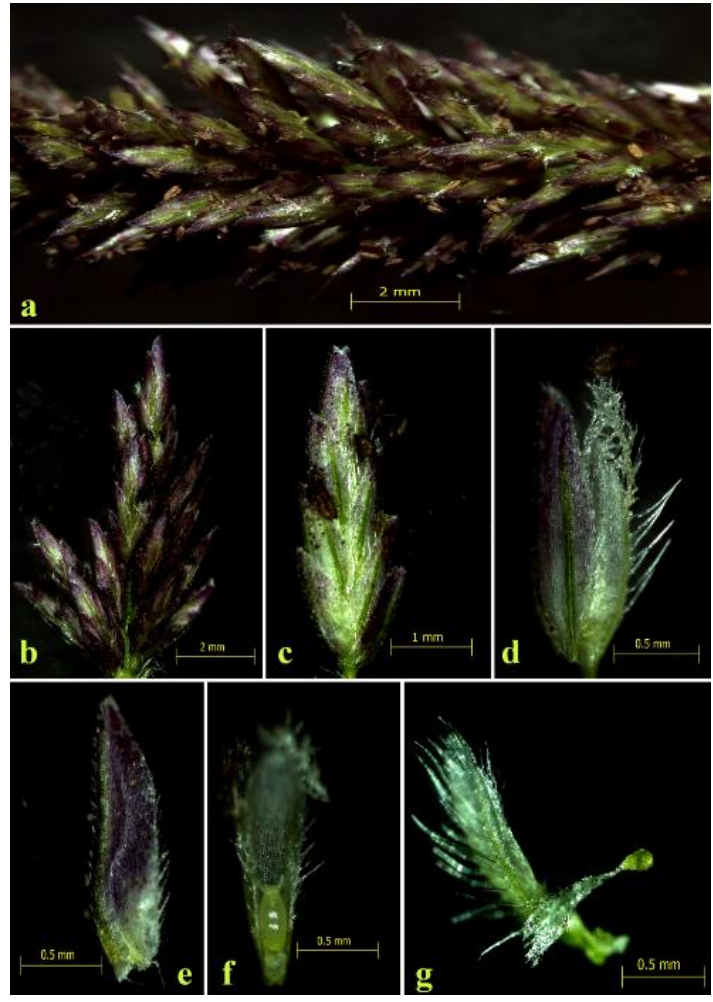

Plate 2. Eragrostis ciliarisa, b \& c. Rachis; d. Spikelet; e. Lemma; f. Palea; g. Pistil.

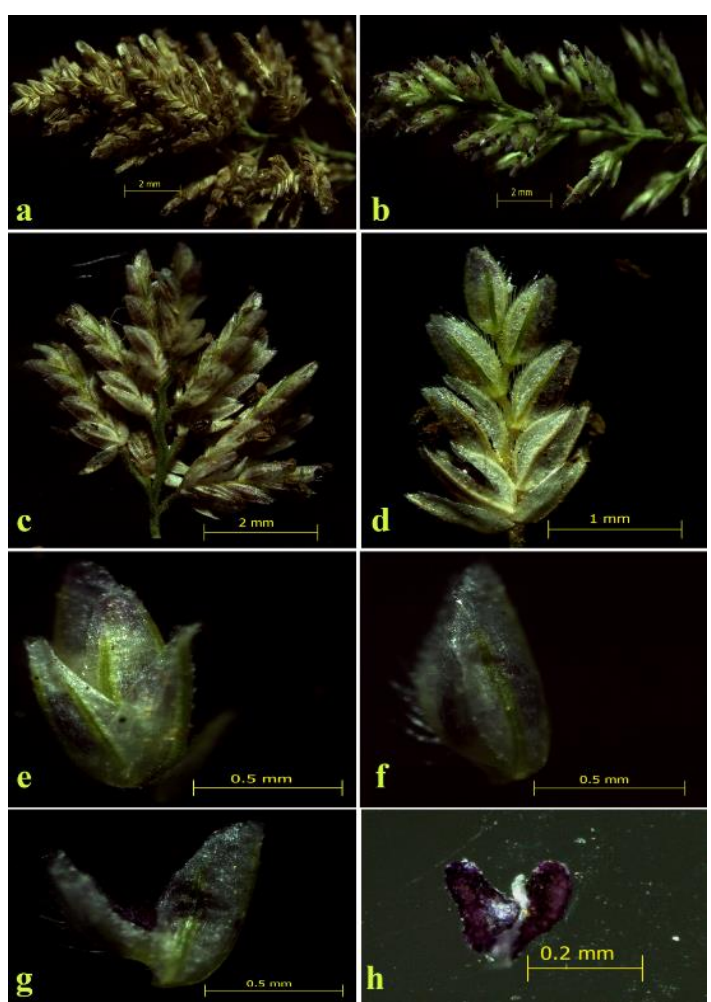

Plate 3. Eragrostis coaratata a, b \& c. Rachis; d \& e. Spikelet; f. Sessile spikelet; g. Lemma and Palea; h. Stamens. 
Eragrostis gangetica (Roxb.) Steud (Plate 4)

Annual. Culms tufted, terete, ascending, slender, glabrous, nodes glabrous. Leaf sheath terete, $2-6 \mathrm{~cm}$ long, mouth glabrous or sparsely hairy, ligule a rim of short hairs. Leaf blade flat, linear, glabrous. Panicles lax, branches filiform. Pedicels capillary, flexuous. Spikelets narrowly oblong, breaking up from below upwards. Lower glume membranous, narrowly ovate, keels scaberulous, 1-nerved, apex acute. Upper glume membranous, narrowly ovate, 1nerved, apex acute. Lemmas membranous, 3-nerved, apex subacute. Palea hyaline, narrowly obovate, keels scabrid, persistent. Lodicules 2. Stamens 3. Caryopsis ovate.
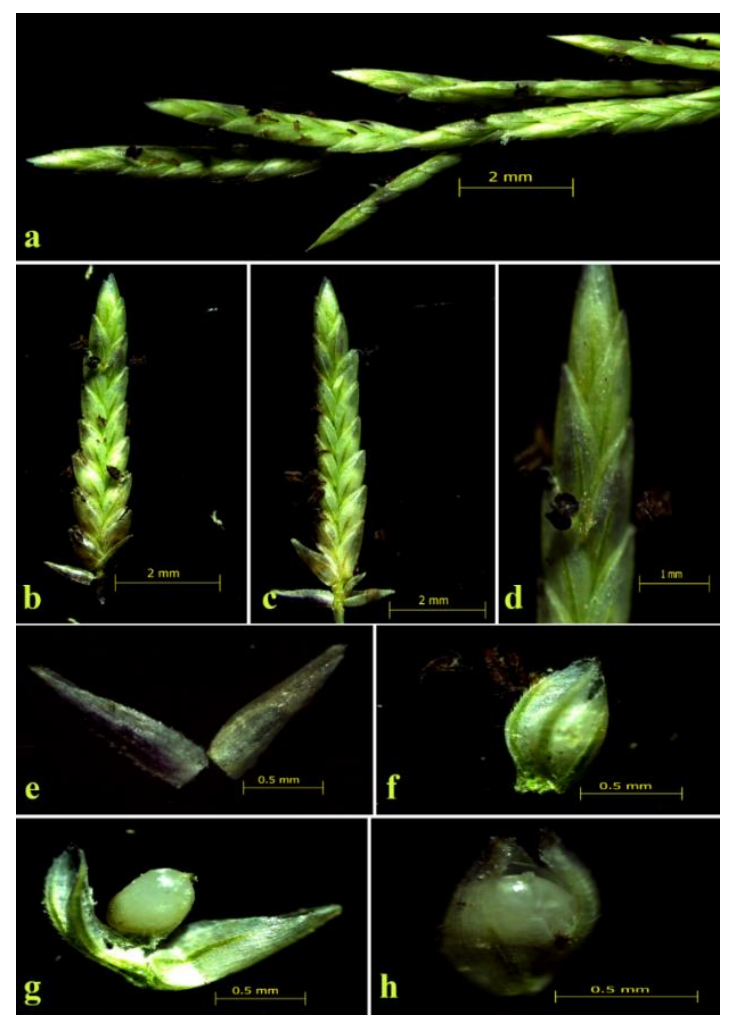

Plate 4. Eragrostis gangetica a. Rachis; b, c \& d. Spikelet; e. Lower glumeand upper glume; f. Sessile spikelet; g. Lemma and Palea; h. Lemma and Palea with caryopsis.

Eragrostis unioloides (Retz.) Nees ex. Steud (Plate 5)

Annual. Culms tufted, terete, Geniculately ascending, branched, glabrous. Leaf sheath terete, long ciliate near the mouth, ligule a rim of white hairs. Leaf blade linear ovate, base rounded, apex finely acuminate. Panicles effuse with spreading branches, branches filiform, scaberulous on the angles, hairy at the swollen base. Pedicels longer than the spikelets. Spikelets broadly ovate oblong, breaking up from above downwards. Lower glume membranous, 1keeled, 1-nerved, apex acute. Upper glume membranous, ovate. Lemmas membranous obovate, 2-keeled, 3-nerved. Palea obovate, ciliate on the keels. Lodicules 2. Stamens 3. Caryopsis elliptic.

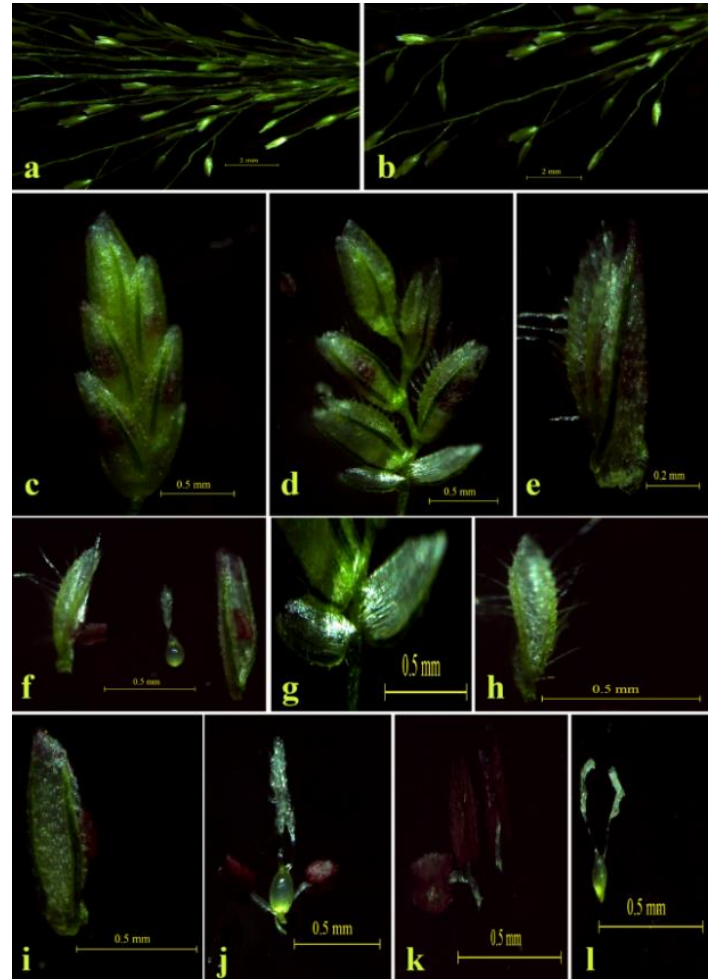

Plate 5. Eragrostis unioloides a $\boldsymbol{\&}$ b. Rachis; c $\boldsymbol{\&}$ d. Spikelet; e. Sessile spikelet; f. Dissect of Spikelet; $\mathbf{g}$. Lower glume and upper glume; h. Palea; i. Lemma; j. Stamens with pistil; k. Stamens; 1. Pistil.

\section{Discussions}

The selected five species of Eragrostis have a single of Narrow elliptical base shaped Silica bodies. This type of silica bodies present over the vascular bundle and mesophyll cells. The highest length of Silica bodies are found Eragrostis atrovirens (18.64 \pm 1.36) [Table No. II (A)] and lowest length found Eragrostis unioloides (11.34 \pm 0.21$)$. Eragrostis ciliaris contain highest breadth $(8.23 \pm 0.75)$ and Eragrostis unioloides contain lowest breadth $(6.02 \pm 0.36)$ [Table No. II (B)]. Showing graphically representation of highest and lowest, length and breadth of Narrow elliptical base shaped Silica bodies in the five taxa of Eragrostis [Graph No. 1]. The linear regression curve of length of Narrow elliptical base shaped silica bodies is done where $\mathrm{R}$ value is 0.78712 , $\mathrm{t}$ value is 13.02665 and probability value is 2.00423 which is significant in 0.05 levels but not significant in 0.001 levels [Graph No. 2]. The linear regression curve of breadth of Narrow elliptical base shaped silica bodies is done where $\mathrm{R}$ value is 0.32819 , $\mathrm{t}$ value is 16.16152 and probability value is 8.57469 which is significant in 0.05 levels but not significant in 0.001 levels [Graph No. 2]. 


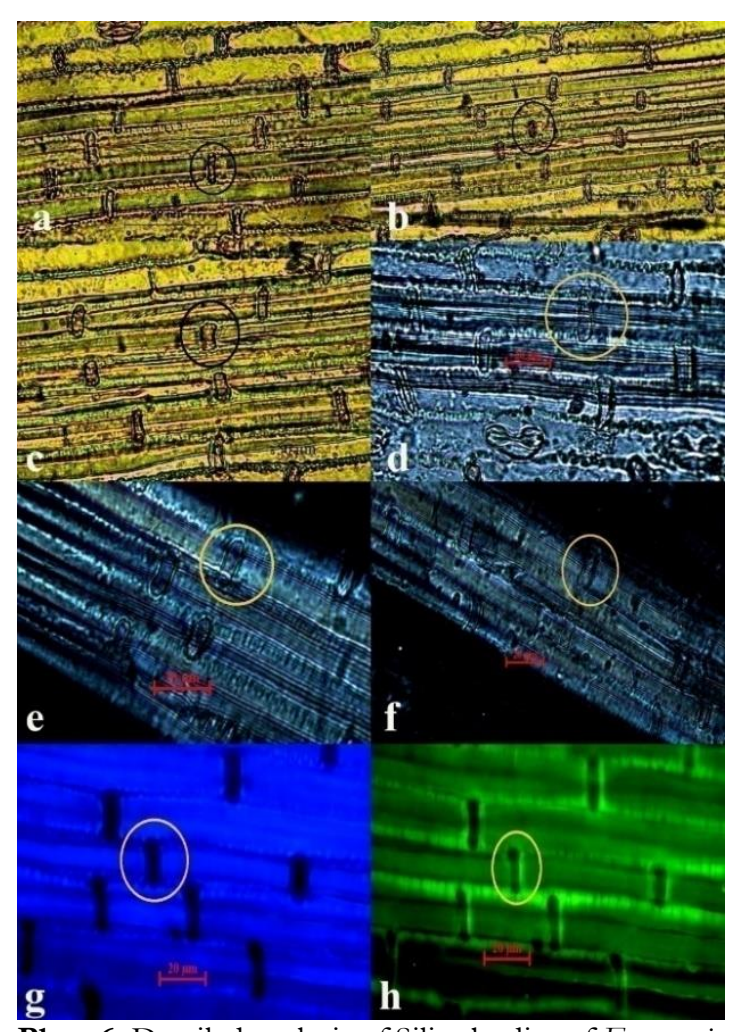

Plate 6. Detailed analysis of Silica bodies of Eragrostis atrovirens under LM (a, b, c, d), PM (e, f), FM ( - UV light and h-blue light).

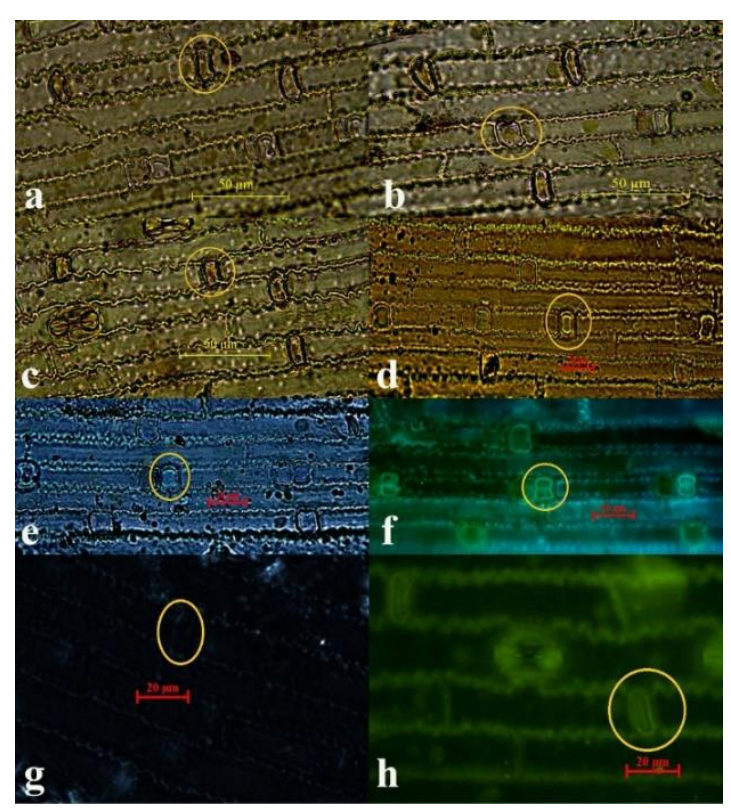

Plate 7. Detailed analysis of Silica bodies of Eragrostis ciliaris under LM (a, b, c, d, e), PM (g), FM (f, h-blue light).

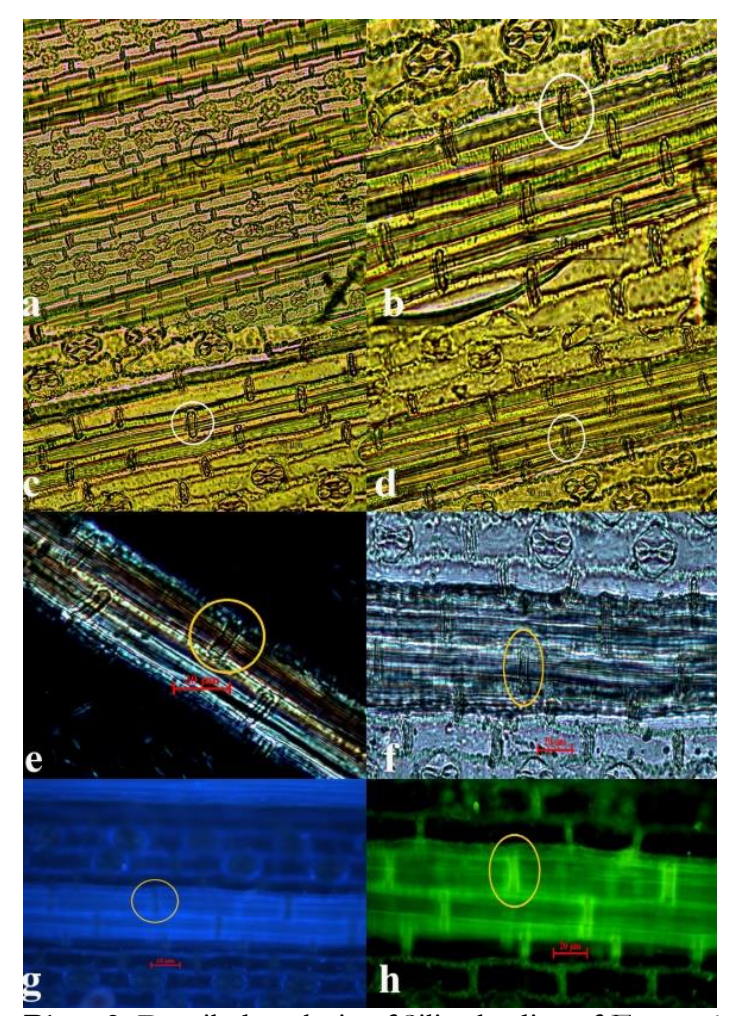

Plate 8. Detailed analysis of Silica bodies of Eragrostis coaratata under LM (a, b, c, d), PM (e, f), FM (g - UV light and $\mathrm{h}$-blue light).

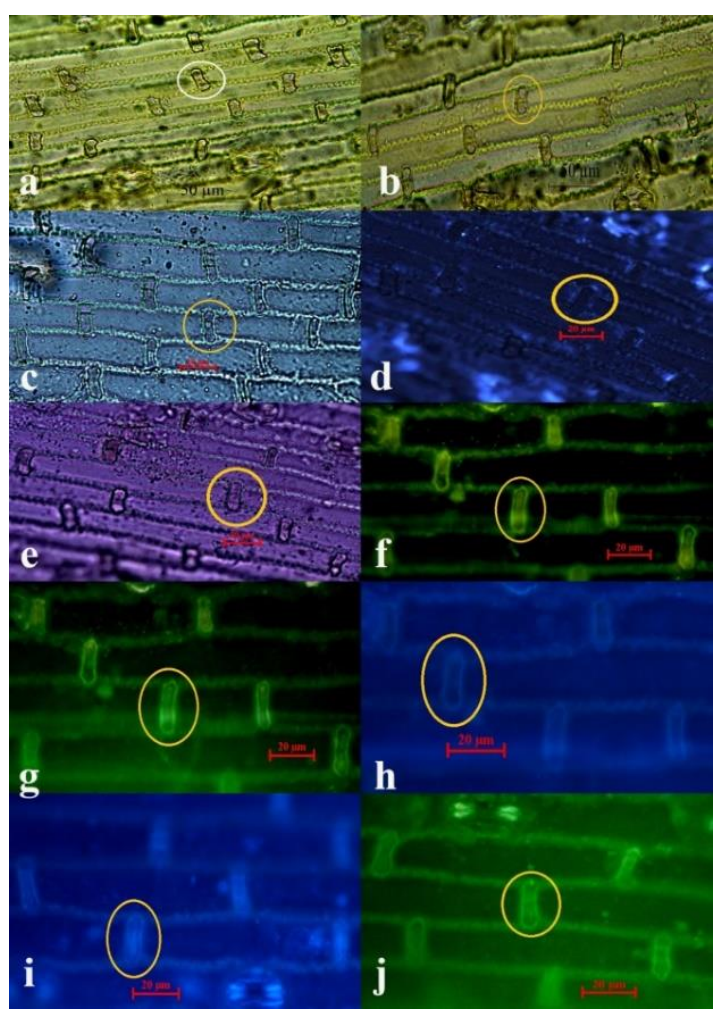

Plate 9. Detailed analysis of Silica bodies of Eragrostis gangetica under LM (a, b, c, e), PM (d), FM (h, i - UV light and $f, g, j$-blue light). 


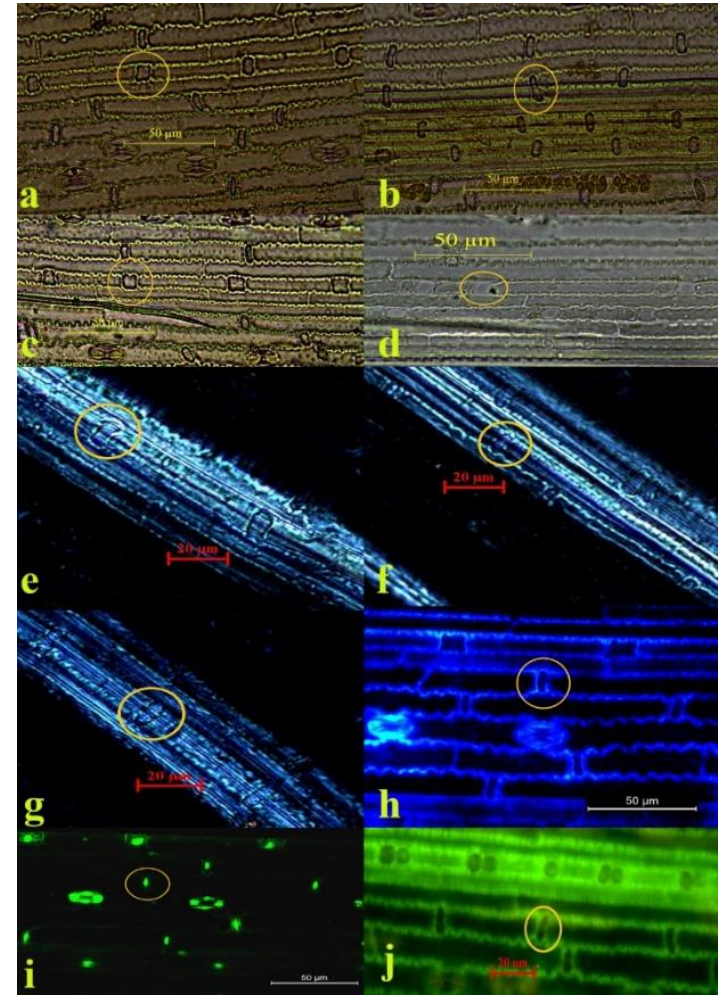

Plate 10. Detailed analysis of Silica bodies of Eragrostis unioloides under LM (a, b, c, d), PM (e, f, g), FM (h- UV light and i, j-blue light

Constructed dendrogram based on 10 micromorphological characters of stone cells (Table No. IV and V). The dendrogram constracted through similarity matrix using UPGMA (Unweighted Pair Groups Method with Arithmetic average) any the investigated species.

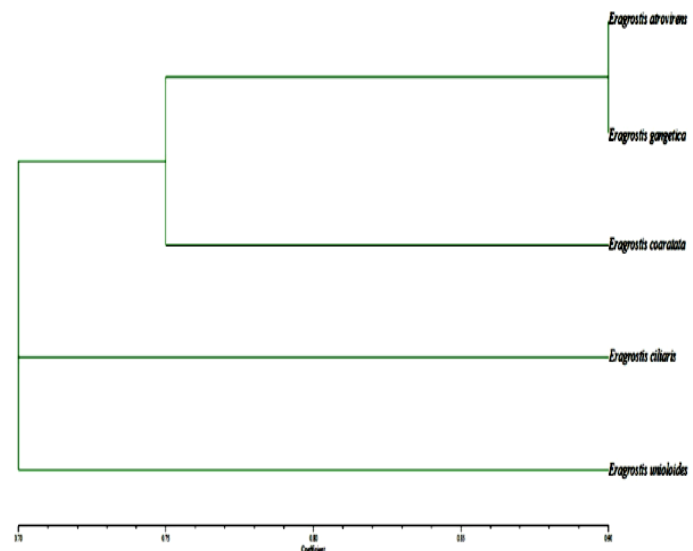

Figure 12. Dendrogram showing co-relation among the 5 species of Eragrostis sp based on micromorphological character of silica bodies.

This dendrogram is showing five species of Eragrostis. Out of them closely related areEragrostis atrovirens and Eragrostis gangetica, their pairing affinity value is $90 \%$. So they are closely related than Eragrostis coaratata (80\%). Other two species Eragrostis ciliaris and Eragrostis unioloides and their pairing value is $70 \%$ (Table No. 5), so they are distantly place.

\section{Conclusions}

Observation and characterization of silica bodies on leaves epidermis were examined in five species of Eragrostis. Five species of Eragrostis belonging to the subfamily Chloridoideae have Narrow elliptical base shaped silica bodies and they are closely related to each other. So, it may be constructed and reframed that, all the species of Eragrostis should be separated from the subfamily Chloridoideae and now shifted to place under the separate subfamily Eragrostioideae. Although it is a single character which is not enough to delimitation and restructuraing of any taxa but taxonomist Takhtajan (1957) has given an example Cuscuta shifted to separate new family Cuscutaceae from Convolvulaceae based on only pollen characters and naw again Cuscuta has been shifted to Convolvulaceae. From that point of view we have suggested to Eragrostis taxa shifted to the new subfamily Eragrostioideae not in previous subfamily Chloridoideae based on silica diversity.

Key to the species based on the micromorphological characters of silica bodies

Plants with only narrow elliptical base shaped

silica bodies

Silica bodies having greater length

Silica bodies having greater breadth Eragrostis

ciliaris

Silica bodies having comparatively shorter Eragrostis

breadth ............

Silica bodies having comparatively shorter length

Silica bodies having greater breadth Eragrostis

............................... gangetica

Silica bodies having moderate breadth Eragrostis

............................ atrovirens

Silica bodies having comparatively shorter Eragrostis

breadth .

coaratata

Graph 1. Graphically representation of length and breadth of Narrow elliptical base shaped silica bodies in the leaf under the sub-family Chloridoideae.
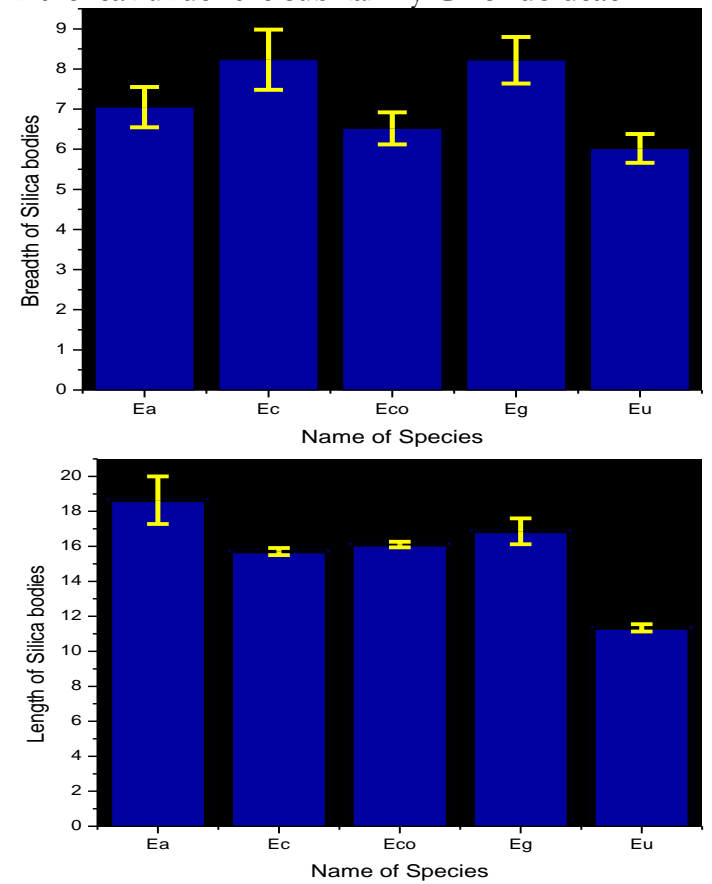
Graph 2. Graphically representation of length and breadth of Narrow elliptical base shaped Silica bodies with Regression, $t$ value and Probability value (linear fit).
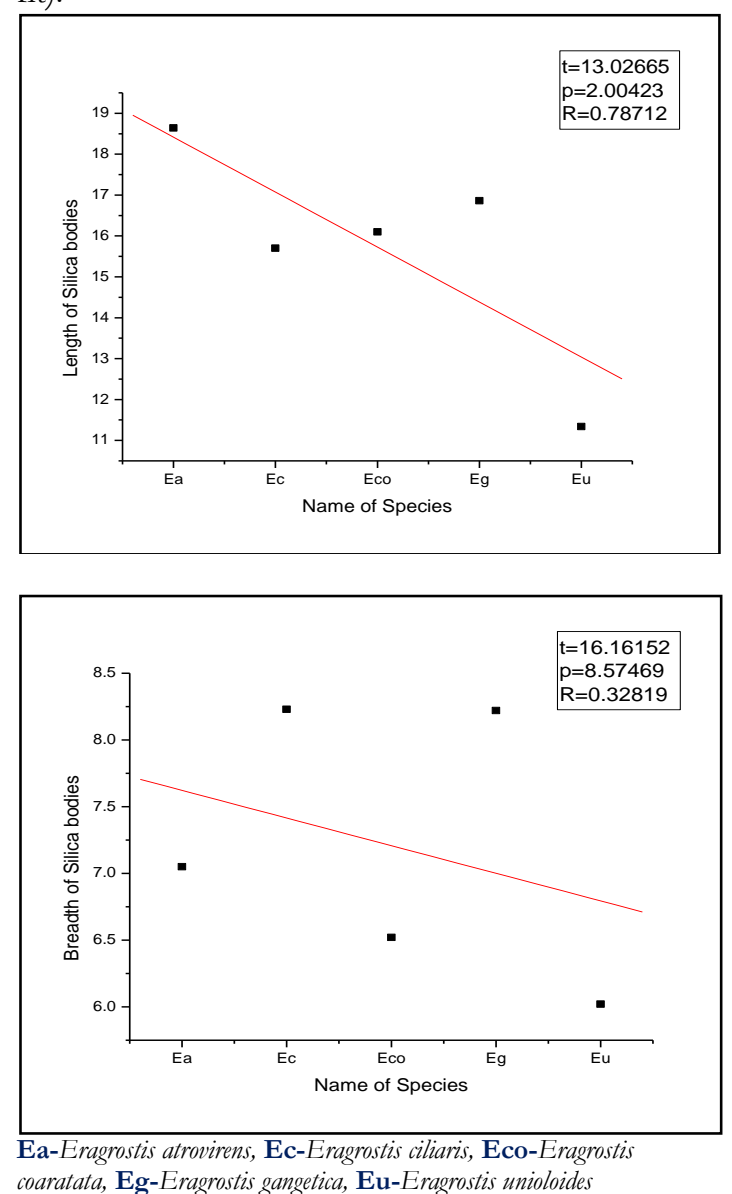

\section{Acknowledgement}

I am highly grateful to UGC-DRS-SAP, New Delhi for their financial support in the form of Research
Project and also thankful my sincere veneration and constant help to my supervisor Prof. Amal Kumar Mondal, FLS, FIAAT, Professor of Botany and Coordinator of the programme, and also thanks to all of the research Scholar of the Plant Taxonomy, Biosystematic and Molecular Taxonomy Laboratory; UGC-DRS-SAP Department, Department of Botany \& Forestry, Vidyasagar University, Midnapore-721102, West Bengal, India. I am also grateful to the Technical staffs of an University Science Instrumentation Centre (USIC), Vidyasagar University as well as the University of Burdwan and Bose Institute, Kolkata.

\section{References}

1. Kaufman PB, Ayanandan P, Franklin CI, and Takeoka Y. Structure and function of silica bodies in the epidermal system of grass shoots. Annals of Botany. 1985, (55), 487-507.

2. Massey FP, Ennos AR and Hartley SE. Silica in grasses as a defence against insect herbivores: contrasting effects on folivores and a phloem feeder. Journal of Animal Ecology. 2006, (75), 595-603,

3. Parry DW, Hodson MJ and Sangster AG. Some recent advances in studies of silicon in higher plants [and Discussion]. Philosophical Transactions of the Royal Society B. 1984, (304), 537-549.

4. Shakoor, SA. Silicon to silica bodies and their potential roles: An overview. International Journal of Agricultural Sciences. 2014, 4(2), 111-120.

\section{Cite this article as:}

Shilpa Dinda and Amal Kumar Mondal. The morphometric and numerical analysis of five species of Eragrostis sp. Wolf. based on leaf epidermal cells Silica bodies. Annals of Plant Sciences 7.5 (2018) pp. 2213-2219.

do $\mathrm{http://dx.doi.org/10.21746/aps.2018.7.5.2}$

Source of support: UGC-DRS-SAP, New Delhi, India.

Conflict of interest: Nil 